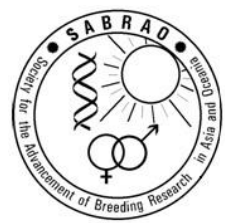

\title{
COMBINING ABILITY AND HETEROTIC STUDIES ON HYBRID MELON (Cucumis melo L.) POPULATIONS FOR FRUIT YIELD AND QUALITY TRAITS
}

\author{
K. BADAMI ${ }^{1 *}$, B.S. DARYONO ${ }^{2}$, A. AMZERI ${ }^{1}$ and S. KHOIRI ${ }^{1}$ \\ ${ }^{1}$ Faculty of Agriculture, University of Trunojoyo Madura, Indonesia \\ ${ }^{2}$ Faculty of Biology, Gadjah Mada University, Indonesia \\ *Corresponding author email: badami61.kb@gmail.com \\ Email addresses of coauthors: bs_daryono@mail.ugm.ac.id, aamzeri@gmail.com, \\ syaiful.khoiri@trunojoyo.ac.id
}

\section{SUMMARY}

In different crop plants, combining ability and heterosis are used as important diagnostic tools for assessing the performance of parental genotypes and their hybrids. This research aimed to evaluate heterotic and combining ability effects in the diallel crosses of melon (Cucumis melo L.) for yield- and quality-related traits. Seven melon (C. melo L.) genotypes were grown and crossed in a complete diallel fashion to produce $F_{1}$ hybrids. During the 2019 crop season, 49 melon genotypes ( 7 parents $+42 F_{1}$ hybrids) were grown in a randomized complete block design with three replications. Observations were made for seven characters. Analysis of variance revealed significant $(P \leq 0.01)$ differences among the melon genotypes for harvest age, fruit flesh thickness, fruit total soluble solids, fruit length, and fruit diameter and merely significant differences $(P \leq 0.05)$ for fruit weight. Combining ability analysis revealed that mean squares due to general combining ability (GCA) were significant for fruit diameter but were nonsignificant for all other traits. However, mean squares due to specific combining ability (SCA) were significant for all traits. The parental genotypes PK-165, PK-464, and PK-669 exhibited the highest and desirable GCA effects for yield and quality traits. Hence, these genotypes could be used to generate high-yielding hybrid/open-pollinated cultivars. GCA:SCA ratios further revealed that the traits of harvest age, fruit flesh thickness, fruit total soluble solids, fruit length, and fruit weight were controlled by dominant gene action, whereas fruit diameter was managed by additive and dominant genes. The majority of the traits were controlled by nonadditive gene action, verifying that the said breeding material could be efficiently used for the production of hybrid cultivars on the basis of heterotic effects.

Keywords: Diallel crosses, combining ability, heritability, heterosis, Cucumis melo L., choice of parents 
Key findings: Six hybrids were identified as potential melon populations. The majority of the traits were also controlled by nonadditive gene action, showing room for the production of melon (C. melo L.) hybrid cultivars.

Manuscript received: June 9, 2020; Decision on manuscript: October 18, 2020; Accepted: October $30,2020$.

(C) Society for the Advancement of Breeding Research in Asia and Oceania (SABRAO) 2020

Communicating Editor: Dr. Samrin Gul

\section{INTRODUCTION}

Melon (Cucumis melo L.) is an important summer-maturing fruit crop that is widely cultivated worldwide and has a vast range of different types (Paris et al., 2012; Makful et al., 2017). It has a high economic value and can be planted in tropical and subtropical regions (Ariesta and Rifah, 2016). Indonesia is one of the largest melon-producing countries in Southeast Asia, producing 117,344 tons (6859 ha) during 2016, 92,446 tons (15724 ha) during 2017, and 118,708 tons (6773 ha) during 2018 (FAO, 2018). However, in Indonesia, local melon production meets only approximately $40 \%$ of domestic needs, and the remaining $60 \%$ is imported (Annisa and Gustia, 2017).

The scarcity of improved melon cultivar seeds, which are still imported from Taiwan, Thailand, and Japan, is one of major hurdles encountered in increasing melon production in Indonesia (Zulfikri et al., 2015). During 2017, the need for melon seed in Indonesia reached 4.1 tons, whereas domestic melon seed production was only 3.0 tons (BPS, 2017). Given the shortage of superior melon seeds, melon cultivation has become expensive and unprofitable for farming communities in Indonesia. Assembling hybrid melon cultivars with superior characters is an approach toward meeting the need for melon seeds in Indonesia and to reducing dependency on imported melon seeds.

Melon plant breeding programs aim to increase fruit yield, improve fruit quality, and enhanced resistance to major diseases (Khumaero et al., 2014; Napolitano et al., 2020). Highyielding melon cultivars must have high production, uniform shape and size, and good fruit quality (Zalapa et al., 2006). Character uniformity can be obtained from uniform melon genotypes that may be homozygous or heterozygous. Homozygotes are found in pure strains, whereas heterozygotes are found in hybrid cultivars. Hybrid melon cultivars are more desirable than pure melon strains because of their better characters and appearance and higher production (Choudary et al., 2018).

Hybrid melon cultivars with desirable traits can be generated through diallel crosses performed among several parental genotypes to obtain the best new combinations (Barros et al., 2011; Zhang and Kang, 1997). Diallel analysis can provide information on general combining ability (GCA) and specific combining ability (SCA) for parental genotypes and their hybrids, respectively (Chukwu et al., 2016; Fasahat et al., 2016). Such information is needed to identify potential parents with good combining ability and crosses with desired characters among Egyptian melon genotypes (Selim, 2019). The $F_{1}$ hybrids obtained through diallel 
crosses can have desirable heterotic effects and can exceed the parental genotypes in terms of performance (Amzeri, 2015; Liu et al., 2019). Past research on combining ability and heterosis in complete diallel crosses reported desirable fruit weight and maturity in melon (Feyzan et al., 2009). However, research on combining ability and heterosis using the complete diallel crosses of melon for yield and quality-related traits remains insufficient. Therefore, the present research was designed to evaluate the combining ability and heterotic effects in $7 \times 7$ diallel crosses of melon for yield and quality traits.

\section{MATERIALS AND METHODS}

\section{Plant material and procedure}

Seven melon genotypes, i.e., PK-165, PK-269, D-12, PK-464, PK-610, PK669, and PK-361 (six lines originated from Sumenep Regency, Madura Island, Indonesia, and one line was introduced from China), were grown during June-September 2018 and were crossed in a complete diallel fashion to produce $F_{1}$ hybrids (Table 1 , Figure 1). During the 2019 cropping season, 49 melon genotypes (7 parents $+42 F_{1}$ hybrids) were grown in a randomized complete block design with three replications. The research location, i.e., Pamekasan, Madura Regency, Indonesia, is located at latitude $7^{\circ} 02 \mathrm{~S}$ and longitude $113^{\circ} 32$ $E$ at an altitude of $250 \mathrm{~m}$. This location has the following conditions: average annual rainfall of $1461 \mathrm{~mm}$, temperature of $27{ }^{\circ} \mathrm{C}-30{ }^{\circ} \mathrm{C}$, alfisol soil type, and $\mathrm{pH}$ of 7.1.

The seeds of all the genotypes were grown in polybags with dimensions of $5 \mathrm{~cm} \times 5 \mathrm{~cm}$, and each experimental unit consisted of 10 plants. Ten-day-old melon plants were moved to beds with dimensions of 3.0 $\mathrm{m} \times 1.2 \mathrm{~m} \times 0.7 \mathrm{~m}$ (length $\times$ width $\times$ height) with plant and row spacings of $60 \mathrm{~cm}$. Basic fertilization was carried out during tillage at the rate of $150 \mathrm{~kg}$ NPK ha-1 $(2: 2: 1)$, and organic manure was applied at the rate of 10 ton ha ${ }^{-1}$. NPK fertilizer was also applied at weekly intervals at the rate of $2 \mathrm{~g}$ per plant. After the plants had entered the generative phase, NPK fertilization was performed at the rate of $3 \mathrm{~g}$ per plant with weekly intervals. Insect pests of melon plants were controlled by using the insecticides Curacorn 500 EC and Decis 25 EC. Melon plant diseases were controlled by using the fungicides Antracol 70 WP, Dithane M4580 WP, and Agri-mycin 17.

\section{Data collection and statistical analysis}

For each parameter, the data were recorded by using five randomly selected melon plants in each subplot. The parameter measurements are presented in Table 2 . All the recorded data were subjected to analysis of variance to test the null hypothesis that no differences existed among the melon parental genotypes and their $F_{1}$ populations (Steel et al., 1997). Duncan's new multiple range test (DMRT) was used for means separation and comparison after significance. The data of all the parameters of the seven melon parental genotypes and $42 \mathrm{~F}_{1}$ hybrids were further subjected to combining ability analysis in accordance with Griffing's (1956) Method-I based on Eisenhart's Model-II (Singh and Chaudhary, 1985). Variance, 
combining ability, and heterosis out by using the PBTools, STAR, and Excel programs.

\section{RESULTS AND DISCUSSION}

Analysis of variance revealed significant $(P \leq 0.01)$ differences among the melon (C. melo L.) analyses were carried genotypes for harvest age, fruit flesh thickness, fruit total soluble solids, fruit length, and fruit diameter and merely significant $(P \leq 0.05)$ differences for fruit weight. These results indicated great genetic variability among the parental genotypes and their $F_{1}$ hybrids (Table $3)$.

Table 1. Descriptions of the melon parental genotypes used in the present research.

\begin{tabular}{|c|c|}
\hline $\begin{array}{l}\text { Parental } \\
\text { genotypes }\end{array}$ & Fruit description \\
\hline PK-165 & $\begin{array}{l}\text { Local line: large round fruit; green fruit skin; white flesh color; medium flesh; } \\
\text { medium aroma; tight but uneven net }\end{array}$ \\
\hline PK-269 & $\begin{array}{l}\text { Local line: large round fruit; yellow-green rind; white green flesh color; } \\
\text { medium flesh; medium aroma; tight and even net }\end{array}$ \\
\hline D-612 & $\begin{array}{l}\text { Introduction line: round and medium-sized fruit; green skin color; orange fruit } \\
\text { flesh color; crispy flesh; no aroma; tenuous and uneven net }\end{array}$ \\
\hline PK-464 & $\begin{array}{l}\text { Local line: large round fruit; green fruit skin; green-white flesh color; medium } \\
\text { flesh; medium aroma; tight and even net }\end{array}$ \\
\hline PK-610 & $\begin{array}{l}\text { Local line: large round fruit; green fruit skin; white flesh color; medium flesh; } \\
\text { medium aroma; tight and even net }\end{array}$ \\
\hline PK-669 & $\begin{array}{l}\text { Local line: large round fruit; cream-colored fruit skin; white green flesh color; } \\
\text { soft flesh; fragrant aroma; tenuous and even net }\end{array}$ \\
\hline PK-361 & $\begin{array}{l}\text { Local line: large round fruit; cream-colored fruit skin; white green flesh color; } \\
\text { soft flesh; fragrant aroma; tight and even net }\end{array}$ \\
\hline
\end{tabular}

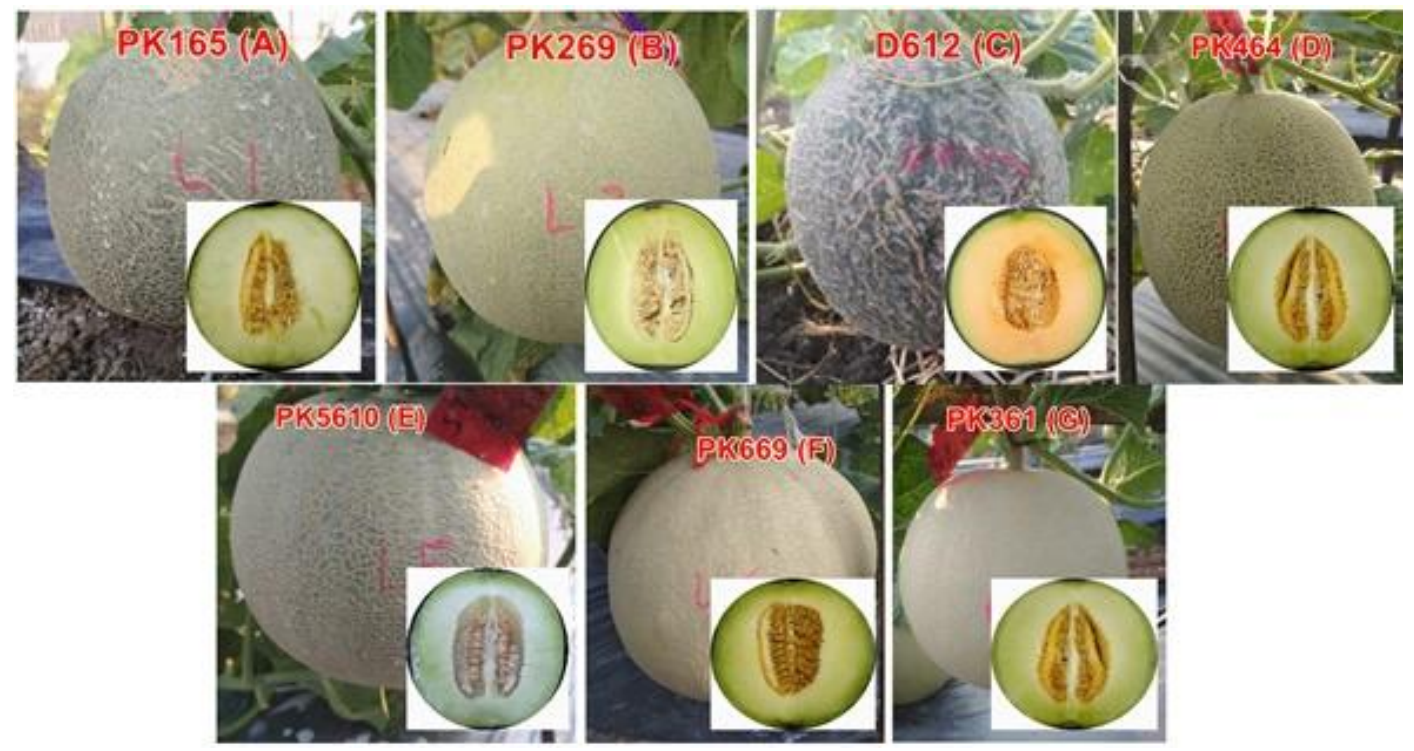

Figure 1. Melon parental genotypes used in the present study. 
SABRAO J. Breed. Genet.52 (4) 402-417

Table 2. Measurement of observation parameters.

\begin{tabular}{ll}
\hline Parameters & Measurement \\
\hline Harvest age (days) & $\begin{array}{l}\text { Calculated on the basis of the physiological maturity of } \\
\text { melon fruits with the following characteristics, i.e., the net } \\
\text { is visible, the skin color changes from green to yellow, the } \\
\text { skin is fully colored, the fruit stalks turn yellow and the } \\
\text { ring around the melon fruit stalk appears cracked (in } \\
\text { melon mesh), and fragrant aroma }\end{array}$ \\
\hline Fruit total soluble solids ( ${ }^{\circ}$ brix) & $\begin{array}{l}\text { measured at the tip, middle, and base of melon fruit flesh } \\
\text { by using a hand refractometer }\end{array}$ \\
\hline Fruit flesh thickness $(\mathrm{cm})$ & $\begin{array}{l}\text { measured by cutting the melon fruit transversely at the } \\
\text { end, middle, and bottom }\end{array}$ \\
\hline Fruit length $(\mathrm{cm})$ & $\begin{array}{l}\text { measured from the base to the tip of the melon fruit } \\
\text { Fruit diameter }\left(\mathrm{cm}^{2}\right)\end{array}$ \\
\hline Fruit weight $(\mathrm{g})$ & $\begin{array}{l}\text { all the fruits were collected from each melon plant and } \\
\text { then collectively weighed }\end{array}$ \\
\hline
\end{tabular}

Table 3. Analysis of variance for various yield-related traits in melon.

\begin{tabular}{llllllll}
\hline \multirow{2}{*}{$\begin{array}{l}\text { Sources of } \\
\text { variation }\end{array}$} & d.f. & $\begin{array}{l}\text { Harvest } \\
\text { age }\end{array}$ & $\begin{array}{l}\text { Fruit } \\
\text { flesh } \\
\text { thickness }\end{array}$ & $\begin{array}{l}\text { Fruit total } \\
\text { soluble } \\
\text { solids }\end{array}$ & $\begin{array}{l}\text { Fruit } \\
\text { length }\end{array}$ & $\begin{array}{l}\text { Fruit } \\
\text { diameter }\end{array}$ & $\begin{array}{l}\text { Fruit } \\
\text { weight }\end{array}$ \\
\hline Replications & 2 & 0.13 & 0.01 & 1.31 & 0.29 & 0.32 & 80758.99 \\
Genotypes & 48 & $2.20^{* *}$ & $0.83^{* *}$ & $4.51^{* *}$ & $2.99 * *$ & $3.01^{* *}$ & $61094.27^{*}$ \\
Error & 96 & 0.06 & $0.18^{* *}$ & 0.38 & 0.27 & 0.26 & 40143.80 \\
CV $(\%)$ & - & 5.42 & 13.01 & 15.04 & 13.87 & 12.99 & 19.19 \\
\hline
\end{tabular}

Note: $*, * *=$ significant at $5 \%$ and $1 \%$ level of probability; d.f. $=$ degrees of freedom

\section{GCA and SCA}

Combined analysis of variance revealed that in $C$. melo L., mean squares due to GCA were significant for fruit diameter but were nonsignifcant for all other traits (Table 4). However, mean squares due to SCA were significant for all the traits. Akrami and Arzani (2019) revealed that in melon genotypes, mean squares due to GCA and SCA are significant for fruit diameter and other yield- and quality-related traits. The results further revealed that harvest age, fruit flesh thickness, fruit total soluble solids, fruit length, and fruit weight were controlled by dominant genes, whereas fruit diameter was controlled by additive and dominant gene action. Characters with high and significant GCA effects are controlled by additive genes, whereas traits with higher SCA effects than GCA effects are controlled by dominant genes (Ferreira et al., 2004). The results showed a GCA:SCA ratio $<0.50$ for all characters. Therefore, the action of dominant genes controlled all characters, and the melon cultivar assembly program should be directed toward the utilization of heterosis effects. Other studies on combining ability showed that the majority of the characters in cucumber et al., 
Table 4. Analysis of variance for combining ability, GCA:SCA variances and ratio, and heritability estimates for various traits in melon.

\begin{tabular}{|c|c|c|c|c|c|c|c|}
\hline \multirow[b]{2}{*}{$\begin{array}{l}\text { Sources of } \\
\text { variation }\end{array}$} & \multirow[b]{2}{*}{ d.f. } & \multicolumn{6}{|c|}{ Mean squares } \\
\hline & & $\begin{array}{l}\text { Harvest } \\
\text { age }\end{array}$ & $\begin{array}{l}\text { Fruit } \\
\text { flesh } \\
\text { thickness }\end{array}$ & $\begin{array}{l}\text { Fruit total } \\
\text { soluble } \\
\text { solids }\end{array}$ & $\begin{array}{l}\text { Fruit } \\
\text { length }\end{array}$ & $\begin{array}{l}\text { Fruit } \\
\text { diameter }\end{array}$ & $\begin{array}{l}\text { Fruit } \\
\text { weight }\end{array}$ \\
\hline GCA & 6 & 0.46 & 0.13 & 2.25 & 1.51 & $1.65^{*}$ & 23639.92 \\
\hline SCA & 21 & $0.68 * *$ & $0.42 * *$ & $1.93 * *$ & $0.68 * *$ & $0.65 * *$ & 28417.69* \\
\hline Reciprocals & 21 & $0.87 * *$ & $0.18 * *$ & $0.86 * *$ & $1.17 * *$ & $1.17 * *$ & 12152.30 \\
\hline Error & 96 & 0.02 & 0.01 & 0.13 & 0.08 & 0.09 & 13415.43 \\
\hline$\sigma^{2} g$ & & 0.00 & 0.00 & 0.03 & 0.06 & 0.07 & 1923.80 \\
\hline$\sigma^{2} s$ & & 0.37 & 0.24 & 1.03 & 0.34 & 0.32 & 7260.30 \\
\hline$\sigma^{2} r$ & & 0.42 & 0.09 & 0.37 & 0.55 & 0.54 & 7414.43 \\
\hline GCA:SCA ratio & & 0.00 & 0.00 & 0.05 & 0.06 & 0.30 & 0.35 \\
\hline$\sigma^{2} A$ & & 0.00 & 0.00 & 0.11 & 0.24 & 0.29 & 0.00 \\
\hline$\sigma^{2} D$ & & 1.49 & 0.94 & 4.11 & 1.36 & 1.29 & 34191.21 \\
\hline$\sigma^{2} G$ & & 1.49 & 0.94 & 4.21 & 1.60 & 1,58 & 34191.21 \\
\hline$\sigma^{2} E$ & & 0.02 & 0.01 & 0.13 & 0.07 & 0,08 & 13296.58 \\
\hline$\sigma^{2} P$ & & 1.51 & 0.95 & 4.34 & 1.67 & 1,66 & 47487.79 \\
\hline$h^{2}$ bs & & 0.99 & 0.99 & 0.97 & 0.96 & 0.95 & 0.72 \\
\hline$h^{2} n s$ & & 0.00 & 0.00 & 0.02 & 0.14 & 0.17 & 0.00 \\
\hline $\mathrm{h}_{\mathrm{ns}}^{2} / \mathrm{h}_{\mathrm{bs}}^{2}$ & & 0.00 & 0.00 & 0.02 & 0.15 & 0,18 & 0.00 \\
\hline
\end{tabular}

Note : $*, * *=$ significant at $5 \%$ and $1 \%$ level of probability, respectively; $\mathrm{df}=$ degrees of freedom; $\mathrm{GCA}=$ general combining ability; SCA = specific combining ability; $\sigma^{2} \mathrm{~g}=$ variance due to $\mathrm{GCA} ; \sigma^{2} \mathrm{~s}=$ variance due to SCA; $\sigma^{2} r=$ variance due to reciprocal; $\sigma^{2} A=$ additive variance; $\sigma^{2} D=$ dominant variance; $\sigma^{2} G=$ genetic variance; $\sigma^{2} E=$ environmental variance; $\sigma^{2} P=$ phenotypic variance; $h^{2}{ }_{b s}=$ heritability in the broad sense; $h^{2}{ }_{n s}=$ heritability in the narrow sense

2017), sweet potato (Rukundo et al., 2017), and turnip rape (Sincik et al., 2014), are controlled by dominant genes.

For reciprocals, the mean squares were significant $(P \leq 0.01)$ for harvest age, fruit flesh thickness, fruit total soluble solids, fruit length, and fruit diameter and nonsignificant for fruit weight (Table 4). Alhamdany (2013) revealed that mean squares due to reciprocal effects are significant for fruit diameter and fruit length in the full diallel crosses of melon. In $C$. melo L., the significance of reciprocal effects might be due to extrachromosomal influence on these characters.

Broad-sense heritability was high for all the characters and ranged from 0.72 to 0.99 , which indicated the highest heritability (Stanfield, 1991) (Table 4). Narrow-sense heritability values for all the traits ranged from 0.00 to 0.17 and were lower than broad-sense heritability estimates. Past studies also revealed high broadsense heritability values for various traits of C. melo L., i.e., fruit flesh thickness, fruit length, fruit diameter, and fruit weight (Ibrahim, 2012; Huda et al., 2017; Sakulphrom et al., 2018). Low narrow-sense heritability has been reported for fruit flesh thickness and fruit weight (Mohammadi et al., 2014) and fruit total soluble solids (Javanmard et al., 2018) in melon genotypes. High broad-sense heritability values also indicated that most of the characters in melon were controlled by dominant 
gene action. The contribution of various additive genes could be inferred from the ratio of $\mathrm{h}^{2}{ }_{\mathrm{ns}} / \mathrm{h}^{2}$ bs, which was very low $(0.00$ to 0.18$)$, indicating that that these characters were controlled by dominant genes (Table 4).

The GCA values for various characters of melon parental genotypes are presented in Table 5 . Parents with positive GCA effects can be crossed well given their good combining ability for certain characters (Sprague and Tatum, 1942). Negative GCA values are also required and desirable for certain characters, such as earliness and harvest age (Susanto, 2018). The parents with negative GCA values for harvest age, namely, PK-269 $(-0.32)$ and $\mathrm{D}-612(-0.60)$, could be used to generate early-maturing melon cultivars. In melon parents, the GCA values for other traits varied from each other. PK-669 was the parent with high GCA for fruit total soluble solids. Furthermore, the parental cultivars PK-165, PK-464, and PK-669 exhibited the highest GCA effects for fruit weight. These cultivars can be used to assemble high-yielding hybrid melon cultivars with desirable quality. Parental genotypes with the most desirable and highest GCA have been recorded for okra (Wammanda et al., 2010) and chili (Sitaresmi et al., 2010). Such parental genotypes and their $F_{1}$ hybrids can be used to develop hybrid cultivars or openpollinated cultivars through intensive selection in C. melo L.

In maize crossing programs aiming to produce profitable offspring, the parental cultivars that have high compatibility and combining ability with each other show the highest GCA values (Aguiar et al., 2003; Iriany et al., 2011). The results revealed that in general, the parental genotypes with low GCA effects produced cross combinations with the best and desirable SCA values. This situation indicated that in melon, low $\times$ low GCA parents performed well in producing promising hybrid populations with the best performance for growth, fruit yield, and qualityrelated traits. Parental genotypes with negative GCA values produced promising hybrids, viz., PK-361 $\times$ PK165 , and PK-5610 $\times$ D-612, with the best performance for fruit total soluble solids and fruit weight. Two other parents with negative GCA values also produced desirable $F_{1}$ hybrids, namely, PK-610 $\times$ D-612 and D-612 $\times$ PK-361, with desirable SCA effects and the highest fruit weight and other yieldand quality-related traits. A similar phenomenon in sweet corn is thought to be caused by the effects of beneficial genes in the two parental genotypes that hide nonuseful gene effects and the capability of the parents to combine with each other (Iriany et al., 2011). The same findings were also reported by Akrami and Arzani for fruit total soluble solids (2019) and by Varinder and Vashisht for fruit weight (2018) in their diallel studies on $C$. melo L. The results further emphasized that the parental genotypes with negative GCA values produced the $\mathrm{F}_{1}$ hybrid PK-361 $\times$ PK669 with desirable SCA effects and harvest age. In diallel studies on melon, Feyzan et al. (2009) found that parental genotypes with negative GCA values resulted in offspring with desirable negative SCA effects for harvest age. 
Badami et al. (2020)

Table 5. Estimates for general and specific combining ability effects in parental genotypes and F1 hybrids for various traits in melon.

\begin{tabular}{|c|c|c|c|c|c|c|}
\hline $\begin{array}{l}\text { Parental genotypes } \\
\& \mathrm{~F} 1 \text { hybrids }\end{array}$ & $\begin{array}{l}\text { Harvest } \\
\text { age }\end{array}$ & $\begin{array}{l}\text { Fruit flesh } \\
\text { thickness }\end{array}$ & $\begin{array}{l}\text { Fruit total } \\
\text { soluble solids }\end{array}$ & $\begin{array}{l}\text { Fruit } \\
\text { length }\end{array}$ & $\begin{array}{l}\text { Fruit } \\
\text { diameter }\end{array}$ & $\begin{array}{l}\text { Fruit } \\
\text { weight }\end{array}$ \\
\hline Parental genotypes & \multicolumn{6}{|c|}{ General combining ability effects } \\
\hline PK-165 & 0.09 & $0.25^{* *}$ & -0.02 & -0.09 & 0.06 & $23.27 *$ \\
\hline PK-269 & $-0.32 * *$ & $-0.13 *$ & -0.02 & $-0.54 * *$ & $-0.35^{* *}$ & 3.27 \\
\hline D-612 & $-0.60 * *$ & -0.04 & $-0.20 *$ & $-0.28 *$ & $-0.61 * *$ & $-60.94 *$ \\
\hline PK-464 & $0.28 * *$ & 0.15 & -0.08 & $-0.26^{*}$ & $0.29 *$ & 26.03* \\
\hline PK-610 & $0.15^{*}$ & -0.06 & 0.06 & $0.53 * *$ & $0.21 *$ & $-45.22 *$ \\
\hline PK-669 & $0.18 *$ & $-0.28 * *$ & $0.19 *$ & $0.46 * *$ & 0.19 & $56.01 * *$ \\
\hline PK-361 & $0.21 *$ & 0.11 & -0.03 & 0.17 & $0.21 *$ & -2.42 \\
\hline F1 hybrids & \multicolumn{6}{|c|}{ Specific combining ability effects } \\
\hline PK-165 × PK-262 & $0.27 *$ & 0.06 & $-0.36^{*}$ & -0.15 & $0.22 *$ & $44.73 *$ \\
\hline PK-165 × D-612 & $-0.76 * *$ & $0.47 * *$ & $-0.20 *$ & $-1.08 * *$ & $-0.77 * *$ & $99.11^{* *}$ \\
\hline PK-165 × PK-464 & $0.22 *$ & $-0.23 *$ & $-0.22 *$ & 0.07 & $0.24 *$ & 21.81 \\
\hline PK-165 × PK-610 & $-0.70 * *$ & -0.01 & $0.26 *$ & $-0.72 * *$ & $-0.68 * *$ & $103.56 * *$ \\
\hline $\mathrm{PK}-165 \times \mathrm{PK}-669$ & $-0.64 * *$ & $0.87 * *$ & $0.50 * *$ & -0.15 & $-0.57 * *$ & -17.18 \\
\hline PK-165 × PK-361 & $0.45^{* *}$ & $-0.84 * *$ & -0.15 & $0.80 * *$ & $0.41 *$ & 25.92 \\
\hline PK-269 × PK-165 & -0.03 & 0.00 & $0.33 *$ & $-0.83 * *$ & 0.00 & 7.00 \\
\hline PK-269 × D-612 & $0.16^{*}$ & 0.01 & $0.53 * *$ & $-0.46 * *$ & $0.22 *$ & $116.94 * *$ \\
\hline PK-269 × PK-464 & $0.15^{*}$ & $0.16 *$ & $0.48 * *$ & $0.35^{*}$ & 0.15 & 0.13 \\
\hline PK-269 × PK-610 & $-0.51 * *$ & $-0.46 * *$ & $0.66 * *$ & $0.23 *$ & $-0.52 * *$ & $81.22 * *$ \\
\hline PK-269 × PK-669 & $-0.20 *$ & $-0.41 * *$ & $-0.59 * *$ & $1.30 * *$ & -0.16 & -35.01 \\
\hline PK-269 $\times$ PK-361 & $0.15^{*}$ & $0.20 *$ & 0.07 & $1.26 * *$ & 0.14 & $58.92 *$ \\
\hline D-612 x PK-165 & $0.32 * *$ & $-0.50 * *$ & -0.02 & $0.50 * *$ & $0.25 *$ & -12.83 \\
\hline D-612 × PK-269 & $0.40 * *$ & -0.04 & $-0.28 *$ & $1.00 * *$ & $0.33 *$ & -4.00 \\
\hline D-612 × PK-464 & 0.03 & 0.06 & -0.16 & 0.42 & -0.01 & $97.68 * *$ \\
\hline D-612 $\times$ PK-610 & $0.57 * *$ & $-0.73 * *$ & $-0.25 *$ & $0.80 * *$ & $0.58 * *$ & $-235.36 * *$ \\
\hline D-612 × PK-669 & $0.89 * *$ & $0.66 * *$ & $0.32 *$ & $1.71 * *$ & $0.85^{* *}$ & 12.20 \\
\hline D-612 $\times$ PK-361 & $-0.57 * *$ & $0.28 *$ & $0.33 *$ & $-0.34 *$ & $-0.51 * *$ & $108.30 * *$ \\
\hline PK-464 × PK-165 & $0.32 * *$ & 0.00 & $0.22 *$ & $-0.33^{*}$ & $0.33 *$ & 8.17 \\
\hline PK-464 × PK-269 & $1.73 * *$ & 0.00 & $-0.25^{*}$ & $-0.50 * *$ & $1.83 * *$ & -25.17 \\
\hline PK-464 × D-612 & $0.53 * *$ & 0.00 & 0.00 & $-1.17^{* *}$ & $0.42 *$ & -6.83 \\
\hline PK-464 × PK-610 & $0.15^{*}$ & $-0.42 * *$ & 0.17 & $-0.55^{* *}$ & 0.17 & $67.13 *$ \\
\hline PK-464 × PK-669 & $-0.27 * *$ & $-0.70 * *$ & 0.16 & 0.18 & $-0.31 *$ & -17.44 \\
\hline PK-464 × PK-361 & $0.11 *$ & $0.25 *$ & $-0.47 * *$ & $0.64 * *$ & 0.09 & 41.16* \\
\hline PK-610 × PK-165 & $-0.50 * *$ & 0.00 & $-0.37 *$ & $-0.33 *$ & $-0.50 * *$ & -28.67 \\
\hline PK-610 × PK-269 & $-0.25 *$ & $0.83 * *$ & -0.03 & -0.17 & $-0.25^{*}$ & -6.67 \\
\hline PK-610 × PK-612 & $0.38^{* *}$ & $1.00 * *$ & -0.05 & $1.67 * *$ & $0.42 *$ & $343.80 * *$ \\
\hline PK-610 × PK-464 & $-1.40 * *$ & $0.50 * *$ & 0.06 & 0.00 & $-1.42 * *$ & -30.33 \\
\hline PK-610 × PK-669 & $1.08 * *$ & 0.01 & $0.40 *$ & $-0.94 * *$ & $1.03 * *$ & $61.15^{*}$ \\
\hline PK-610 × PK-361 & $0.53 * *$ & $1.30 * *$ & $0.22 *$ & $-0.48 * *$ & $0.59 * *$ & $56.25 *$ \\
\hline PK-669 × PK-165 & $0.65 * *$ & $-1.33^{* *}$ & 0.00 & $-0.50 * *$ & $0.58 * *$ & -11.17 \\
\hline PK-669 × PK-269 & $-1.25^{* *}$ & $1.00 * *$ & 0.12 & $-0.83 * *$ & $-1.25^{* *}$ & -16.33 \\
\hline PK-669 × D-612 & 0.07 & $0.83 * *$ & $0.25 *$ & $0.83 * *$ & 0.17 & 36.00 \\
\hline PK-669 × PK-464 & 0.08 & 0.00 & $-0.40 *$ & $0.33 *$ & 0.08 & -4.33 \\
\hline PK-669 × PK-610 & -0.07 & $-0.50 * *$ & -0.02 & 0.00 & 0.00 & $-49.00 *$ \\
\hline PK-669 $\times$ PK-361 & $-0.70 * *$ & -0.15 & $-0.23 *$ & $-0.91 * *$ & $-0.73 * *$ & -36.98 \\
\hline PK-361 × PK-165 & $-0.53 * *$ & $0.33 *$ & $0.87 * *$ & -0.17 & $-0.58 * *$ & 24.50 \\
\hline $\mathrm{PK}-361 \times \mathrm{PK}-269$ & $-0.60 * *$ & 0.00 & -0.15 & -0.17 & $-0.58 * *$ & -13.17 \\
\hline PK-361 × D-612 & $-0.20 *$ & 0.17 & 0.03 & $0.50 * *$ & -0.17 & 0.33 \\
\hline PK-361 $\times$ PK-464 & $-0.72 * *$ & 0.00 & $0.25 *$ & $0.50 * *$ & $-0.67 * *$ & 16.50 \\
\hline PK-361 × PK-610 & $-0.55^{* *}$ & 0.17 & 0.08 & 0.17 & $-0.58 * *$ & 12.00 \\
\hline PK-361 × PK-669 & $-1.65^{* *}$ & $-0.50 * *$ & $-0.25^{*}$ & $0.33 *$ & $-1.58^{* *}$ & 36.66 \\
\hline
\end{tabular}

Note : ${ }^{*}, * *=$ significant at $5 \%$ and $1 \%$ level of probability, respectively; d.f. $=$ degrees of freedom 


\section{Heterotic studies}

Heterosis provides information on the best/worst performance for the quantitative traits of $F_{1}$ hybrids as compared with that of the mid (heterosis) and best parents (heterobeltiosis). In musk melon, the heterotic effects over mid and better parents are influenced by overdominant genes in the parental genotypes; genes for quantitative characters are inherited by their descendants (Nerson, 2012). The percentage of heterosis and heterobeltiosis in $F_{1}$ populations with the best performance exceeds the average of both parents and the best parent (Fehr, 1987). Heterosis over the mid and high parent is mainly shown by parental genotypes with distant genetic backgrounds and kinship. In melon fruits, negative heterotic values for harvest age are sought after and found desirable because they reflect a melon genotype's superiority. Negative heterotic values for harvest age over mid and better parents were shown by three crosses, i.e., PK-269 × D-612, PK-610 $\times$ D-612, and PK-669 $\times$ PK269 , and ranged from $-2.61 \%$ to $-3.45 \%$. Moreover, these genotypes were identified as the most earlymaturing cultivars among all the cross combinations (Table 6).

Positive values of heterosis and heterobeltiosis for fruit flesh thickness, fruit total soluble solids, fruit length, fruit diameter, and fruit weight in $C$. melo L. are desirable. The highest positive heterotic values for fruit flesh thickness over mid and better parents were recorded in the crosses PK-269 $\times$ PK-5610, D-612 x PK-269, and PK$269 \times$ PK-269 with the average mean values of $5.00,5.03$, and $5.07 \mathrm{~cm}$, respectively. Among these three $F_{1}$ hybrids, PK-610 × PK-269 exhibited the highest heterosis and heterobeltiosis of $56.00 \%$ and $44.86 \%$, respectively. The highest positive values of heterosis for fruit total soluble solids over the mid and better parents were observed in the $F_{1}$ hybrids D-612 × PK-669, PK-464 × D612, and PK-464 $\times$ PK-361 with average mean values of $15.00,13.33$ and $13.00{ }^{\circ}$ brix, respectively, and the highest percentages were shown by the cross D-612 $\times$ PK-669 (32.35\% and $25.00 \%$ ).

For fruit length characters, the highest heterosis and heterobeltiosis were recorded for the $F_{1}$ hybrids PK$269 \times \mathrm{PK}-464, \mathrm{PK}-5610 \times \mathrm{PK}-464$, and PK-361 $\times$ PK-5610 with maximum heterotic effects in the cross PK-5610 $\times$ PK-464 (14.00\% and $10.68 \%$, respectively) and average mean values of $18.83,19.00$, and $18.50 \mathrm{~cm}$, respectively (Table 7 ). For fruit diameter, the highest values of heterosis over mid and better parents were found for the $F_{1}$ hybrids PK-269 $\times$ PK-464, PK-5610 $\times$ PK-464, and PK-361 $\times$ PK-5610 with mean values of 18.43, 18.45, and $18.12 \mathrm{~cm}^{2}$, respectively. The highest heterotic and heterobeltiotic values for fruit diameter were found for the cross PK$5610 \times \mathrm{PK}-464(0.12 \%$ and $0.08 \%$, respectively). Furthermore, promising heterosis and heterobeltiosis for fruit weight were exhibited by the $F_{1}$ hybrids PK-464 $\times$ PK-669, PK-610 $\times$ PK-464, and PK-669 $\times$ PK-610 with the average mean values of 2239.67 , 2309.33, and $2300.33 \mathrm{~g}$, respectively. The highest heterosis for fruit weight over mid and better parents were noted in $\mathrm{F}_{1}$ hybrid PK-669 $\times$ PK-5610 (19.38\% and $15.42 \%$, respectively). 
Table 6. Estimates of heterosis over the mid parent (MP) and better parent (HP) for harvest age, fruit flesh thickness, and total soluble solids in melon.

\begin{tabular}{|c|c|c|c|c|c|c|c|c|c|}
\hline \multirow[b]{2}{*}{ F1 hybrids } & \multicolumn{3}{|c|}{ Harvest age } & \multicolumn{3}{|c|}{ Fruit flesh thickness } & \multicolumn{3}{|c|}{ Fruit total soluble solids } \\
\hline & $\begin{array}{l}\text { Means } \\
\text { (days) }\end{array}$ & MP (\%) & HP (\%) & $\begin{array}{c}\text { Means } \\
(\mathrm{cm})\end{array}$ & MP (\%) & $\mathrm{HP}(\%)$ & $\begin{array}{l}\text { Means } \\
\left({ }^{\circ} \text { brix }\right)\end{array}$ & MP (\%) & HP (\%) \\
\hline PK-165 × PK-262 & $58.00^{c}$ & 0.00 & 0.00 & $4.27^{\mathrm{e}-\mathrm{i}}$ & 7.20 & -4.40 & $10.67^{a b c}$ & -3.00 & -19.98 \\
\hline $\mathrm{PK}-165 \times \mathrm{D}-612$ & $58.00^{c}$ & 0.87 & 1.72 & $4.00^{\text {de }}$ & -0.41 & -10.45 & $11.33^{\mathrm{a}-\mathrm{e}}$ & -5.58 & -15.03 \\
\hline $\mathrm{PK}-165 \times \mathrm{PK}-464$ & $58.00^{c}$ & -0.85 & -1.69 & $4.23^{d-h}$ & -2.38 & -5.30 & $11.67^{a-f}$ & -2.75 & -12.48 \\
\hline $\mathrm{PK}-165 \times \mathrm{PK}-610$ & $58.00^{c}$ & 0.00 & 0.00 & $4.27^{e-i}$ & 14.38 & -4.40 & $11.67^{a-f}$ & -17.62 & -22.20 \\
\hline PK-165 × PK-669 & $57.33^{c}$ & -0.30 & 0.57 & $5.00^{\mathrm{jk}}$ & 15.83 & 11.94 & $12.00^{b-f}$ & -5.26 & -10.00 \\
\hline $\mathrm{PK}-165 \times \mathrm{PK}-361$ & $57.67^{b c}$ & 0.30 & 1.16 & $5.00^{\mathrm{jk}}$ & 11.52 & 11.94 & $13.00 \mathrm{efg}$ & 4.00 & -2.50 \\
\hline $\mathrm{PK}-269 \times \mathrm{PK}-165$ & $58.00^{c}$ & 0.00 & 0.00 & $3.60^{a b c}$ & -9.62 & -19.40 & $12.33^{c-f}$ & 12.09 & -7.53 \\
\hline PK-269 × D-612 & $56.00^{a}$ & -2.61 & -1.72 & $4.47^{f-i}$ & 26.51 & 25.33 & $12.00^{b-f}$ & 24.14 & 12.50 \\
\hline $\mathrm{PK}-269 \times \mathrm{PK}-464$ & $58.00^{c}$ & -0.85 & -1.69 & $4.47^{f-i}$ & 16.10 & 6.43 & $11.33^{\mathrm{a}-\mathrm{e}}$ & 17.21 & 6.22 \\
\hline $\mathrm{PK}-269 \times \mathrm{PK}-610$ & $58.00^{c}$ & 0.00 & 0.00 & $5.00^{\mathrm{jk}}$ & 53.85 & 42.86 & $12.33^{c-f}$ & 4.20 & -17.80 \\
\hline PK-269 × PK-669 & $58.00^{c}$ & 0.87 & 1.72 & $4.03^{\text {def }}$ & 5.13 & -3.28 & $12.67^{\mathrm{d}-\mathrm{g}}$ & 22.61 & 5.58 \\
\hline PK-269 × PK-361 & $58.00^{c}$ & 0.87 & 1.72 & $4.20^{\mathrm{d}-\mathrm{h}}$ & 5.00 & -6.67 & $13.00 \mathrm{efg}$ & 27.87 & 11.43 \\
\hline D-612 × PK-165 & 59.00 de & 2.61 & 1.72 & 4.03 def & 0.33 & -9.78 & $10.33^{a b}$ & -13.92 & -22.53 \\
\hline D-612 $\times$ PK-269 & $59.33^{\text {ef }}$ & 3.18 & 2.29 & $5.03^{k}$ & 42.36 & 41.03 & $10.00^{a}$ & 3.45 & -6.25 \\
\hline D-612 $\times$ PK-464 & $58.00^{c}$ & 0.00 & -1.69 & $4.00^{\text {de }}$ & 3.00 & -4.76 & $11.00^{a-d}$ & 3.13 & 3.13 \\
\hline D-612 $\times$ PK-610 & $58.00^{c}$ & 0.87 & 0.00 & 4.03 def & 22.74 & 12.99 & $15.00^{h}$ & 16.88 & 0.00 \\
\hline D-612 $\times$ PK-669 & $59.00^{\mathrm{de}}$ & 3.51 & 3.51 & $5.00^{\mathrm{jk}}$ & 29.31 & 20.00 & $15.00^{\mathrm{h}}$ & 32.35 & 25.00 \\
\hline $\mathrm{D}-612 \times \mathrm{PK}-361$ & $58.33^{\text {cde }}$ & 2.33 & 2.33 & $4.57^{\text {hij }}$ & 13.31 & 1.56 & $12.33^{c-f}$ & 10.42 & 5.69 \\
\hline PK-464 × PK-165 & $58.00^{c}$ & -0.85 & 0.00 & $3.80^{\mathrm{bcd}}$ & -12.31 & -14.93 & $12.33^{c-f}$ & 2.75 & -7.53 \\
\hline PK-464 × PK-269 & $58.00^{c}$ & -0.85 & 0.00 & $4.97^{\mathrm{jk}}$ & 29.09 & 18.33 & $12.33^{c-f}$ & 27.55 & 15.59 \\
\hline $\mathrm{PK}-464 \times \mathrm{D}-612$ & $58.00^{c}$ & 0.00 & 1.69 & 4.00 de & 3.00 & -4.76 & $13.33^{\mathrm{fgh}}$ & 24.97 & 24.97 \\
\hline $\mathrm{PK}-464 \times \mathrm{PK}-610$ & $58.00^{c}$ & -0.85 & 0.00 & $3.97^{\text {cde }}$ & 10.28 & -5.48 & $12.00^{b-f}$ & -6.49 & -20.00 \\
\hline PK-464 × PK-669 & $57.00^{\mathrm{b}}$ & -1.72 & 0.00 & $4.20^{d-h}$ & 0.40 & 0.00 & $13.00^{\mathrm{efg}}$ & 14.71 & 8.33 \\
\hline $\mathrm{PK}-464 \times \mathrm{PK}-361$ & $58.33^{\text {cde }}$ & 0.57 & 2.25 & $4.00^{\text {de }}$ & 6.67 & -11.11 & $13.33^{\text {fgh }}$ & 19.37 & 14.26 \\
\hline PK-610 × PK-165 & $58.00^{c}$ & 0.00 & 0.00 & $5.00^{\mathrm{jk}}$ & 33.93 & 11.94 & $12.33^{c-f}$ & -12.96 & -17.80 \\
\hline PK-610 × PK-269 & $56.33^{a}$ & -2.88 & -2.88 & $5.07^{k}$ & 56.00 & 44.86 & $12.67^{\mathrm{d}-\mathrm{g}}$ & 7.07 & -15.53 \\
\hline PK-610 × PK-612 & $56.00^{a}$ & -2.61 & -1.72 & $4.10^{\mathrm{d}-\mathrm{g}}$ & 24.87 & 14.95 & $11.67^{a-f}$ & -9.06 & -22.20 \\
\hline PK-610 $\times$ PK- 464 & $57.00^{b}$ & -2.56 & -3.39 & $5.00^{\mathrm{jk}}$ & 38.89 & 19.05 & $12.00^{b-f}$ & -6.49 & -20.00 \\
\hline PK-610 × PK-669 & $57.00^{b}$ & -0.87 & 0.00 & $4.97^{j k}$ & 38.70 & 19.28 & $12.33^{c-f}$ & -8.67 & -17.80 \\
\hline PK-610 × PK-361 & $59.33^{\text {ef }}$ & 3.18 & 4.02 & $4.67^{j k}$ & 24.53 & 3.78 & $12.67^{\mathrm{d}-\mathrm{g}}$ & -4.97 & -15.53 \\
\hline PK-669 × PK-165 & $60.00^{f}$ & 4.35 & 3.45 & $5.00^{j k}$ & 15.83 & 11.94 & 13.00 efg & -3.70 & -13.33 \\
\hline PK-669 × PK-269 & $56.00^{a}$ & -2.61 & -3.45 & $3.80^{\mathrm{bcd}}$ & -0.87 & -8.80 & $14.33^{\mathrm{gh}}$ & 6.15 & -4.47 \\
\hline PK-669 × D-612 & $57.33^{b c}$ & 0.58 & 0.58 & $4.50^{\mathrm{ghi}}$ & 16.38 & 8.00 & $13.33^{\text {fgh }}$ & -1.26 & -11.13 \\
\hline PK-669 × PK-464 & $57.00^{b}$ & -1.72 & -3.39 & $5.00^{\mathrm{jk}}$ & 19.52 & 19.05 & $12.33^{c-f}$ & -8.67 & -17.80 \\
\hline PK-669 $\times$ PK-610 & $58.00^{\mathrm{c}}$ & 0.87 & 0.00 & $5.00^{\mathrm{jk}}$ & 39.53 & 20.00 & $12.33^{c-f}$ & -8.67 & -17.80 \\
\hline PK-669 × PK-361 & $57.00^{b}$ & 0.00 & 0.00 & $4.00^{\mathrm{de}}$ & -7.69 & -11.11 & $12.33^{c-f}$ & -8.67 & -17.80 \\
\hline PK-361 × PK-165 & $57.00^{b}$ & -0.87 & -1.72 & $3.27^{a}$ & -27.06 & -27.33 & $13.33^{\mathrm{fgh}}$ & 6.64 & -0.03 \\
\hline PK-361 × PK-269 & $58.00^{c}$ & 0.87 & 0.00 & $4.50^{\mathrm{ghi}}$ & 12.50 & 0.00 & $13.33^{\mathrm{fgh}}$ & 31.11 & 14.26 \\
\hline $\mathrm{PK}-361 \times \mathrm{D}-612$ & $58.00^{c}$ & 1.75 & 1.75 & $4.50^{\mathrm{ghi}}$ & 11.57 & 26.17 & $11.33^{a-f}$ & 1.46 & -2.89 \\
\hline $\mathrm{PK}-361 \times \mathrm{PK}-464$ & $58.33^{\text {cde }}$ & 0.57 & -1.14 & $3.50^{a b}$ & -19.54 & -22.22 & $12.33^{c-f}$ & 10.42 & 5.69 \\
\hline $\mathrm{PK}-361 \times \mathrm{PK}-610$ & $59.00^{\mathrm{de}}$ & 2.61 & 1.72 & $4.50^{\mathrm{ab}}$ & 20.00 & 0.00 & $12.33^{c-f}$ & -7.52 & -17.80 \\
\hline PK-361 × PK-669 & $58.00^{c}$ & 1.75 & 1.75 & $4.50^{\mathrm{ghi}}$ & 3.85 & 0.00 & $11.67^{a-f}$ & -1.38 & -2.75 \\
\hline
\end{tabular}

Note: Numbers in one column followed by the same letter show no significant difference based on the DMRT test at the level of a $=5 \%$ 
Table 7. Estimates of heterosis (\%) over the mid parent (MP) and better parent (HP) for fruit length, fruit diameter, and fruit weight in melon.

\begin{tabular}{|c|c|c|c|c|c|c|c|c|c|}
\hline \multirow{2}{*}{ F1 hybrids } & \multicolumn{3}{|c|}{ Fruit length } & \multicolumn{3}{|c|}{ Fruit diameter } & \multicolumn{3}{|c|}{ Fruit weight } \\
\hline & Means $(\mathrm{cm})$ & MP (\%) & HP (\%) & Means $\left(\mathrm{cm}^{2}\right)$ & MP (\%) & HP (\%) & Means $(\mathrm{g})$ & MP (\%) & HP (\%) \\
\hline $\mathrm{PK}-165 \times \mathrm{PK}-262$ & $16.83^{a-f}$ & -1.96 & -7.36 & $16.50^{a-c}$ & -0.04 & -0.11 & $1941.67^{a-f}$ & 0.98 & -2.25 \\
\hline $\mathrm{PK}-165 \times \mathrm{D}-612$ & $15.83^{a b c}$ & -5.49 & -12.86 & $15.45^{a-d}$ & -0.08 & -0.16 & $1868.00^{a-d}$ & -2.14 & -5.96 \\
\hline PK-165 × PK-464 & $17.83^{d-h}$ & 0.92 & -1.85 & 17.44 afg & -0.02 & -0.06 & $2170.00^{c-g}$ & 8.30 & 7.37 \\
\hline PK-165 × PK-610 & $16.00^{a b c}$ & -6.80 & -11.93 & $15.45^{a-d}$ & -0.11 & -0.16 & $1956.33^{a-f}$ & 1.71 & -1.51 \\
\hline PK-165 × PK-669 & $17.17^{c-g}$ & -2.81 & -5.49 & $17.04^{c-g}$ & -0.04 & -0.08 & $2047.67^{a-g}$ & 2.92 & 2.74 \\
\hline $\mathrm{PK}-165 \times \mathrm{PK}-361$ & $17.00^{a-g}$ & -4.23 & -6.42 & $16.47^{a-f}$ & -0.07 & -0.11 & $2025.33^{a-g}$ & 3.67 & 1.96 \\
\hline PK-269 $\times$ PK-165 & $16.83^{a-f}$ & -1.96 & -7.36 & $16.46^{a-f}$ & -0.05 & -0.11 & $1950.33^{a-f}$ & 1.43 & -1.81 \\
\hline PK-269 × D-612 & $16.50^{a-d}$ & 4.76 & 2.06 & $16.25^{a-f}$ & 0.04 & 0.01 & $1819.33^{a}$ & -1.41 & -2.15 \\
\hline PK-269 × PK-464 & $18.83^{\mathrm{gh}}$ & 12.98 & 9.69 & $18.43^{\mathrm{g}}$ & 0.11 & 0.08 & $2183.67^{\text {afg }}$ & 12.55 & 8.05 \\
\hline PK-269 × PK-610 & $16.00^{a b c}$ & -1.03 & -1.03 & $15.46^{a-d}$ & -0.04 & -0.04 & $1935.67^{a-f}$ & 4.07 & 4.03 \\
\hline PK-269 × PK-669 & $15.33^{a b}$ & -8.02 & -10.70 & $15.06^{a b}$ & -0.09 & -0.12 & $1797.00^{\mathrm{a}}$ & -6.71 & -9.83 \\
\hline PK-269 $\times$ PK-361 & $16.33^{a-d}$ & -2.51 & -5.79 & $16.06^{\mathrm{a}-\mathrm{e}}$ & -0.03 & -0.06 & $1983.33^{a-f}$ & 4.93 & 3.24 \\
\hline D-612 x PK-165 & $15.33^{a b}$ & -8.48 & -15.61 & 15.06 & -0.10 & -0.19 & $1854.00^{a b}$ & -2.87 & -6.66 \\
\hline D-612 $\times$ PK-269 & $15.83^{a b c}$ & 0.51 & -2.08 & $15.43^{a-d}$ & -0.01 & -0.04 & $1930.67^{a-f}$ & 4.62 & 3.84 \\
\hline D-612 $\times$ PK-464 & $17.00^{a-g}$ & 4.62 & -0.97 & $17.04^{c-g}$ & 0.06 & 0.00 & $2064.33^{a-g}$ & 7.17 & 2.14 \\
\hline D-612 $\times$ PK-610 & $17.50^{\mathrm{c}-\mathrm{h}}$ & 11.11 & 8.25 & $17.23^{d-g}$ & 0.11 & 0.07 & $2080.67^{a-g}$ & 12.71 & 11.82 \\
\hline D-612 $\times$ PK-669 & $17.50^{c-h}$ & 7.69 & 1.94 & $17.24^{d-g}$ & 0.07 & 0.01 & $2222.67^{e-g}$ & 16.24 & 11.52 \\
\hline D-612 $\times$ PK-361 & $15.83^{\mathrm{abc}}$ & -3.08 & -8.67 & $15.43^{a-d}$ & -0.04 & -0.10 & $1922.67^{a-g}$ & 2.48 & 0.09 \\
\hline PK-464 × PK-165 & $17.17^{\mathrm{c}-\mathrm{g}}$ & -2.81 & -5.49 & $17.04^{\mathrm{c}-\mathrm{g}}$ & -0.04 & -0.08 & $2037.67^{a-g}$ & 1.70 & 0.82 \\
\hline PK-464 × PK-269 & $15.17^{a}$ & -8.98 & -11.63 & $15.22^{a b c}$ & -0.08 & -0.11 & $1855.00^{a b c}$ & -4.39 & -8.21 \\
\hline PK-464 × D-612 & $16.17^{\mathrm{a}-\mathrm{d}}$ & -0.49 & -5.81 & $16.03^{a-e}$ & 0.00 & -0.06 & $1929.33^{a-f}$ & 0.16 & -4.54 \\
\hline $\mathrm{PK}-464 \times \mathrm{PK}-610$ & $16.17^{a-d}$ & -2.98 & -5.81 & $16.03^{a-e}$ & -0.03 & -0.06 & $1961.67^{a-f}$ & 1.07 & -2.94 \\
\hline PK-464 × PK-669 & $17.17^{\mathrm{c}-\mathrm{g}}$ & 0.02 & 0.02 & $17.04^{c-g}$ & 0.00 & 0.00 & $2239.67^{\mathrm{fg}}$ & 11.59 & 10.82 \\
\hline PK-464 × PK-361 & $16.83^{a-f}$ & -2.43 & -2.90 & $16.44^{a-f}$ & -0.04 & -0.04 & $2096.33^{a-g}$ & 6.36 & 3.73 \\
\hline PK-610 × PK-165 & $17.00^{a-g}$ & -0.97 & -6.42 & $16.45^{a-f}$ & -0.05 & -0.11 & 2186.67 efg & 13.68 & 10.09 \\
\hline PK-610 × PK-269 & $16.50^{a-d}$ & 2.06 & 2.06 & $16.24^{a-f}$ & 0.01 & 0.01 & $2031.33^{a-g}$ & 9.21 & 9.17 \\
\hline PK-610 $\times$ PK -612 & $16.67^{\mathrm{a}-\mathrm{e}}$ & 5.84 & 3.11 & $16.26^{a-f}$ & 0.05 & 0.01 & $2028.67^{a-g}$ & 9.90 & 9.03 \\
\hline PK-610 × PK-464 & $19.00^{\mathrm{h}}$ & 14.00 & 10.68 & $18.45^{\mathrm{g}}$ & 0.12 & 0.08 & $2309.33^{g}$ & 18.99 & 14.27 \\
\hline PK-610 × PK-669 & $18.33^{\mathrm{e}-\mathrm{h}}$ & 9.98 & 6.78 & $18.05^{\mathrm{fg}}$ & 0.09 & 0.06 & $2202.33^{\text {efg }}$ & 14.30 & 10.50 \\
\hline PK-610 × PK-361 & $17.33^{c-h}$ & 3.46 & -0.02 & $17.05^{c-g}$ & 0.03 & 0.00 & $2200.00^{\text {efg }}$ & 16.35 & 14.52 \\
\hline PK-669 × PK-165 & $16.00^{a b c}$ & -9.43 & -11.93 & $15.45^{a-d}$ & -0.13 & -0.16 & $1955.67^{a-f}$ & -1.71 & -1.87 \\
\hline PK-669 × PK-269 & $17.83^{d-h}$ & 6.98 & 3.86 & $17.44^{\text {efg }}$ & 0.05 & 0.02 & 2220.00 efg & 15.25 & 11.39 \\
\hline PK-669 × D-612 & $17.17^{\mathrm{c}-\mathrm{h}}$ & 5.66 & 0.02 & $17.06^{c-g}$ & 0.06 & 0.00 & $2150.67^{\mathrm{b}-\mathrm{g}}$ & 12.47 & 7.91 \\
\hline PK-669 × PK-464 & $17.00^{a-g}$ & -0.97 & -0.97 & $16.46^{a-f}$ & -0.03 & -0.03 & $2089.33^{a-g}$ & 4.10 & 3.38 \\
\hline PK-669 × PK-610 & $18.33^{\mathrm{e}-\mathrm{h}}$ & 9.98 & 6.78 & $18.06^{\mathrm{fg}}$ & 0.09 & 0.06 & $2300.33^{g}$ & 19.38 & 15.42 \\
\hline PK-669 × PK-361 & $15.00^{\mathrm{a}}$ & -13.04 & -13.46 & $14.45^{\mathrm{a}}$ & -0.15 & -0.15 & $1862.00^{\mathrm{a}-\mathrm{d}}$ & -4.85 & -6.57 \\
\hline PK-361 × PK-165 & $18.17^{\mathrm{e}-\mathrm{h}}$ & 2.37 & 0.02 & $18.04^{\mathrm{fg}}$ & 0.01 & -0.02 & 2201.67 efg & 12.69 & 10.84 \\
\hline PK-361 × PK-269 & $17.50^{c-h}$ & 4.48 & 0.96 & $17.25^{\mathrm{d}-\mathrm{g}}$ & 0.04 & 0.07 & $2166.33^{b-g}$ & 14.61 & 12.77 \\
\hline PK-361 x D-612 & $16.17^{a-d}$ & -1.00 & -6.71 & $16.04^{\text {a-e }}$ & 0.00 & 0.07 & $1963.33^{a-f}$ & 4.65 & 2.20 \\
\hline PK-361 × PK-464 & $18.17^{\mathrm{e}-\mathrm{h}}$ & 5.33 & 4.83 & $18.05^{\mathrm{fg}}$ & 0.06 & 0.06 & $2227.67^{\mathrm{efg}}$ & 13.02 & 10.23 \\
\hline PK-361 $\times$ PK-610 & $18.50^{\mathrm{fgh}}$ & 10.45 & 6.73 & $18.12^{\mathrm{fg}}$ & 0.10 & 0.11 & $2176.00^{d-g}$ & 15.08 & 13.27 \\
\hline PK-361 × PK-669 & $18.17^{\mathrm{e}-\mathrm{h}}$ & 5.33 & 4.83 & $18.05^{\mathrm{fg}}$ & 0.06 & 0.06 & $2159.33^{b-g}$ & 10.34 & 8.35 \\
\hline
\end{tabular}

Note: Numbers in one column followed by the same letter show no significant difference based on the DMRT test at the level of a $=5 \%$ 


\section{Selection of potential parental genotypes and F1 hybrids}

In the majority of crop plants, combining ability and heterotic effects are needed to determine potential parents and their hybrids for assembling hybrids and openpollinated cultivars in future breeding programs (Wiguna, 2015). A hybrid with high SCA values does not always exhibit the best heterosis because for SCA, all the cross combinations are tested and compared, whereas for heterosis, the $F_{1}$ hybrid is compared only with the two parents. Therefore, for the selection of a promising hybrid, attention must be paid to the GCA of the parental genotypes, the SCA of $F_{1}$ hybrids, and the estimations of heterosis and heterobeltiosis in the said hybrid. The best hybrid can be produced and selected through the cross-breeding of parental genotypes on the basis of desirable GCA and SCA effects and heterosis over mid and better parents for the desired traits (Roy, 2000).

The results of this study revealed that melon hybrid cultivars with the best mean performance for desirable traits, i.e., early maturity and high sugar content, could be developed on the basis of GCA, SCA, and heterotic effects. In melon fruits, the highest production is based on fruit weight. In muskmelon, fruit flesh thickness, fruit length, and fruit diameter are supporting characters and are positively correlated with fruit weight (Mehta et al, 2009; Sakulphrom, 2018). In melon, fruit weight is high if it exceeds $2000 \mathrm{~g}$, and harvest age is considered as early if it is less than 70 days (IPGRI, 2003). In melon, fruit total soluble solids is the most desirable trait and must be higher or equal to $10^{\circ}$ brix for

Table 8. Average of fruit weight (>2000 g), heterosis value (\%) and combining ability.

\begin{tabular}{|c|c|c|c|c|c|}
\hline F1 hybrids & $\mathrm{MP}(\%)$ & $\mathrm{HP}(\%)$ & Means $(\mathrm{g})$ & SCA effects & GCA effects \\
\hline PK-610 × PK-464 & 14.00 & 10.68 & 2309.33 & -30.30 & $\mathrm{PK}-165=23.27$ \\
\hline PK-669 × PK-610 & 9.98 & 6.78 & 2300.33 & -49.00 & PK-464 = 26.03 \\
\hline PK-464 × PK-669 & 0.02 & 0.02 & 2239.67 & -17.44 & $\mathrm{PK}-361=56.01$ \\
\hline PK-361 x PK-464 & 5.33 & 4.83 & 2227.67 & 16.50 & \\
\hline D-612 × PK-669 & 7.69 & 1.94 & 2222.67 & 12.20 & \\
\hline PK-669 × PK-269 & 6.98 & 3.86 & 2220.00 & -16.33 & \\
\hline PK-610 × PK-669 & 9.98 & 6.78 & 2202.33 & 61.15 & \\
\hline PK-361 × PK-165 & 2.37 & 0.02 & 2201.67 & 24.50 & \\
\hline PK-610 × PK-361 & 3.46 & -0.02 & 2200.00 & 56.25 & \\
\hline PK-610 × PK-165 & -0.97 & -6.42 & 2186.67 & -28.67 & \\
\hline PK-269 × PK-464 & 12.98 & 9.69 & 2183.67 & 0.13 & \\
\hline PK-361 × PK-610 & 10.45 & 6.73 & 2176.00 & 12.00 & \\
\hline PK-165 × PK-464 & 0.92 & -1.85 & 2170.00 & 44.73 & \\
\hline PK-361 × PK-269 & 4.48 & 0.96 & 2166.33 & -13.17 & \\
\hline PK-361 × PK-669 & 5.33 & 4.83 & 2159.33 & 36.66 & \\
\hline PK-669 × D-612 & 5.66 & 0.02 & 2150.67 & 36.00 & \\
\hline PK-464 × PK-361 & -2.43 & -2.9 & 2096.33 & 41.16 & \\
\hline PK-669 × PK-464 & -0.97 & -0.97 & 2089.33 & -4.33 & \\
\hline D-612 × PK-610 & 11.11 & 8.25 & 2080.67 & -235.36 & \\
\hline$D-612 \times P K-464$ & 4.62 & -0.97 & 2064.33 & 97.68 & \\
\hline PK-165 × PK-669 & -2.81 & -5.49 & 2047.67 & -17.18 & \\
\hline PK-464 × PK-165 & -2.81 & -5.49 & 2037.67 & 8.17 & \\
\hline PK-610 × PK-269 & 2.06 & 2.06 & 2031.33 & -6.67 & \\
\hline PK-610 × D-612 & 5.84 & 3.11 & 2028.67 & 343.80 & \\
\hline PK-165 × PK-361 & -4.23 & -6.42 & 2025.33 & 25.92 & \\
\hline
\end{tabular}


commercial varieties (United Nations Economic Commission for Europe, 2017).

For melons, the recommended harvest age is the early age category (56-60 days), and fruit total soluble solids should be equal or more than $10^{\circ}$ brix (10-15 ${ }^{\circ}$ brix). All the present $F_{1}$ hybrids meet the criteria for superior melon cultivars, and the direction of breeding should be based on these two important traits. Fruit weight should be considered further because the other two characters, i.e., harvest age and fruit total soluble solids, meet the criteria of superiority in all the cross combinations. The highest production could be obtained from the diallel crosses of melon genotypes with the highest fruit weight $(>2000 \mathrm{~g})$. Several $F_{1}$ hybrids with fruit weights of above $2000 \mathrm{~g}$ with promising heterosis and combining ability were observed in the present melon diallel populations (Table 8).

The selection of cross combinations to be released as hybrid cultivars is mainly based on GCA and SCA values, heterosis, and heterobeltiosis. The best hybrid must have desirable GCA parents, attractive SCA values, and heterotic effects. On the basis of these criteria, six melon $F_{1}$ hybrids, namely, PK-361 × PK-464, D$612 \times$ PK-669, PK-610 × PK-669, PK$361 \times$ PK-165, PK-361 $\times$ PK-669, and PK-669 $\times$ D-612, were identified and selected as superior hybrid cultivars with good yield potential and desirable quality traits. These six hybrids had desirable mean values for harvest age (56-59 days), fruit total soluble solids (11.67-15.00 $\left.{ }^{\circ} \mathrm{brix}\right)$, and fruit weight $(2150.62-2227.67 \mathrm{~g})$. Thus, these promising hybrids can be used as candidate genotypes for release as hybrid melon cultivars with early maturity, high sugar content, and increased yield with desirable quality.

\section{CONCLUSIONS}

Most traits, i.e., harvest age, fruit flesh thickness, fruit total soluble solids, fruit length, and fruit weight, were controlled by dominant genes. GCA:SCA ratios were less than 0.50 for all the traits, confirming that all the characters were controlled by dominant gene action. Therefore, the melon cultivar assembly program should be directed toward the utilization of heterotic effects. The parental genotypes PK-165, PK-464, and PK-669 exhibited high GCA values for fruit weight. The $F_{1}$ hybrids PK-361 $\times$ PK-464, D-612 x PK-669, PK-610 × PK-669, PK-361 $\times$ PK-165, PK-361 $\times$ PK-669, and PK-669 $\times$ D-612 were identified and selected as promising cross combinations on the basis of GCA and SCA values and heterotic effects for harvest age, fruit total soluble solids, and fruit weight. These candidate genotypes could be used as a source population for the development of melon hybrid cultivars with early maturity and increased sugar content, yield, and quality.

\section{ACKNOWLEDGEMENTS}

This work was a part of cooperative between University of Trunojoyo Madura and Gadjah Mada University. This work was also supported by grant from the University of Trunojoyo Madura through the University's Independent Research Scheme. 


\section{REFERENCES}

Aguiar AM, Carlini-Garcia LA, de Silva AR, Santos MF, Garcia AAF, de Souza CL (2003). Combining ability of inbred lines of maize and stability of their respective single-crosses. Scien. Agricola. 60(1): 83-89.

Akrami M, Arzani A (2019). Inheritance of fruit yield and quality in melon (Cucumis melo L.) grown under field salinity stress. Sci. Reports .9:1-13.

Alhamdany SYH (2013). Combining ability for yield and its components in melon (Cucumis melo L) depending on full-diallel cross. Mesopatamia J. Agric. 41(1): 91-105.

Amzeri A (2015). Plant Breeding Basics. UTM-Press. Bangkalan, Indonesia.

Annisa P, Gustia H (2017). Response of growth and production of melon plants to the provision of liquid organic fertilizer thitonia diversifiola. Proceedings of the National Seminar on Sustainable Agriculture and Herbal Plants in Indonesia. pp. 104-114.

Ariesta GR, Rifah A (2016). Phenotypic traits of Cucumismelo L.cv. Tacapa and commercial melon cultivars based on multi location and multi season trials. AIP Conference Proceedings. pp. 1-7.

Barros AKA, Nunes GHS, Queiroz MA, Pereira EWL, Filho JHC (2011). Diallel analysis of yield and quality traits of melon fruits diallel analysis of yield and quality traits of melon fruits. Crop Breed. Appl. Biotechnol. 11: 313-319.

Bhutia TL, Munshi AD, Behera TK, Sureja AK, Lal SK (2017). Combining ability for yield and yield related traits and its relationship with gene action in cucumber. Indian J. Hort. 74(1): 51-55.

BPS (2017). Statistics of Indonesian seasonal vegetables and fruits. Statistics Center of Indonesia (BPS). Jakarta, Indonesia.

Choudary BR, Haldhar SM, Maheshwari SK (2018). Identification and possibility of monoecious inbred of muskmelon (Cucumis melo L.) for heterosis breeding. Veg. Sci. 45(1): 118-120.

Chukwu S, Okporie EO, Onyishi GC, Ekwu LG, Nwogbaga AC, Ede NV (2016). Application of diallel analysis in crop improvement. Agric. Biol. J. N. Am. 7(2): 95-106.

Dehghani H, Feyzan E7, Jalali M, Rezai A, Dane F (2011). Use of GGE biplot methodology for genetic analysis of yield and related traits in melon (Cucumis melo L.). Can. J. Plant Sci. 92: 77-85.

FAO (2018). Food and Agricultural Organization (FAO), United Nations.

Fasahat P, Rajabi A, Rad JM, Derera J (2016). Principles and utilization of combining ability in plant breeding. Biom. Biostat. Int. J. 4(1): 1-22.

Fehr WR (1987). Principles of cultivar development, theory and technique. McMillan Pub. Comp. New York.

Ferreira FM, Ribeiro Júnior JI, Pacheco CAP, Silva CHO, Filho SM (2004). Genetic components of combining ability in a complete Diallel. Crop Breed. Appl. Biotechnol. 4: 338343.

Feyzan E, Dehghani H, Rezai AM, Javaran MJ (2009). Diallel cross analysis maturity and yield-related traits in melon (Cucumis melo L.). Euphyta. 168: 215-223.

Griffing B (1956). Consepts of general and specific combining ability in relation to diallel crossing system. Aust. J. Biol. Sci. 9:436-493.

Huda AN, Suwarno WB, Maharijaya A (2017). Genetic diversity of fruit traits among 17 melon genotypes (Cucumis melo L.). J. Hort. Indonesia. 8(1): 1-12.

Ibrahim EA (2012). Variability, heritability and genetic advance in Egyptian sweet melon (Cucumis melo var. Aegyptiacus L.) under water stress conditions. Int. J. Plant Breed. Genet. 6(4): 238-244. 
IPGRI (2003). Deskriptors for melon (Cucumis melo L.). International Plant Genetic Resources Institute. Rome, Italy.

Iriany RN, Sujiprihati $S$, Syukur $M$, Koswara J, Yunus M (2011). Evaluation of combining ability and heterosis of five sweet corn lines (Zea mays var. saccharata) through diallel crossing. J. Agron. Indonesia. 39:103-111.

Javanmard J, Saleh-abadi FS, Bihamta MR (2018). Estimation of some genetic parameters through generation mean analysis in melon. Indian $\mathrm{J}$. Agric. Res. 355:1-6.

Khumaero WW, Efendi D, Suwarno WB, Sobir (2014). Evaluation of horticultural characteristics of four melon genotypes (Cucumis melo L.) from centre tropical horticulture study IPB. J. Hort. Indonesia. 5(1): 56-63.

Liu J, Li M, Zhang Q, Wei X, Huang X (2019). Exploring the molecular basis of heterosis for plant breeding. J. Integ. Plant Biol. 62(3): 287-298.

Makful, Hendri, Sahlan, Sunyoto, Kuswandi (2017). Character of melon fruit lines on generation $S_{6}$ and $\mathrm{S}_{7}$. Bull. Plasma Nutfah. 23(1): 1-12.

Mehta R, Singh D, Bhalala MK (2009). Correlation and path analysis in muskmelon. Indian J. Hort. 66(3): 396-399.

Mohammadi R, Dehghani H, Karimzadeh G (2014). Genetic analysis of yield components, early maturity and total soluble solids in cantaloupe (Cucumis melo L. subsp. Melovarcantalupensis Naudin). Yuzuncu YII University (YYU) $\mathrm{J}$. Agric. Sci. 24(1): 79-86.

Napolitano M, Terzaroli N, Kashyap S, Russi L, Evans EJ, Albertini E (2020). Exploring heterosis in melon (Cucumis melo L.). Plants. 9: 1-19.

Nerson H (2012). Heterosis in fruit and seed characters of musk melon.
Asian Aust. J. Plant Sci. Biotechnol. 6(1): 24-27.

Paris HS, Amar Z, Lev E (2012). Medieval emergence of sweet melons, Cucumis melo (Cucurbitaceae). Ann. Bot. 110: 23-33.

Roy D (2000). Plant breeding, analysis and exploitation of variation. Narosa Publishing House, New Delhi.

Rukundo P, Shimelis H, Laing M, Gahakwa D (2017). Combining ability, maternal effects, and heritability of drought tolerance, yield and yield components in sweet potato. Front. Plant Sci. 7: 1-14.

Sakulphrom S, Chankaew S, Sanitchon J (2018). Genetics analysis and heritability of fruit characters in muskmelon (Cucumis melo L.) using extreme parental differences. AGRIVITA J. Agric. Sci. 40 (1): 1-7.

Selim MAM (2019). Heterosis and combining ability for some fruit quality traits of Egyptian melon inbred lines using line $x$ tester analysis. Egyptian J. Agric. Res. 7(1): 317-342.

Sincik M, Sozen E, Falk KC, Goksoy AT, Acikgoz E (2014). Heterosis and combining ability in a diallel cross of turnip rape genotypes. Turk. J. Field Crops. 19(2): 228-234.

Singh RK, Chaudhary BD (1985). Biometrical method in quantitative genetics analysis. Kalyani Publications, Ludhiana, New Dehli, India.

Sitaresmi T, Sujiprihati S, Syukur M (2010). Combining ability of several introduced and local chili pepper (Capsicum annuum L.) genotypes and heterosis of the off springs. J. Agron. Indonesia. 38(3):212-217.

Sprague GF, Tatum LA (1942). General vs. specific combining ability in single crosses of corn. J. Am. Soc. Agron. 34: 923-932.

Stanfield WD (1991). Genetica $2^{\text {nd }}$ Edition. Erlangga. Jakarta, Indonesia.

Steel RGD, Torrie JH, Dickey DA (1997). Principles and Procedures of 
Statistics: A Biometrical Approach, $3^{\text {rd }}$ ed. McGraw Hill Book Co., Inc., New York.

Susanto GWA (2018). Estimation of gene action through combining ability for maturity in soybean. SABRAO J. Breed. Genet. 50(1): 62-71.

United Nation Economic Commission for Europe (2017). Melon. UNECE Standard FFV-23 Concerning Marketing and Commercial Quality Control of MELONS 2017 edition. United Nations. New York.

Varinder S, Vashisht VK (2018). Heterosis and combining ablity for yield in muskmelon (Cucumis melo L.). Int. J. Curr. Microbiol. Appl. Sci. 7(8): 2996-3006.

Wammanda DT, Kadams AM, Jonah PM (2010). Combining ability analysis and heterosis in a diallel cross of okra (Abelmoschus esculentus L. Moench). Afr. J. Agric. Res. 5(16): 2108-2115.

Wiguna G, Sumpena U (2015). Evaluation of heterosis and heterobeltiosis value of some cucumber crosses (Cucumis sativus L.) at different altitude. J. Hort. 26(1): 1-8.

Zalapa JE, Staub JE, McCreight JD (2006). Generation means analysis of plant architectural traits and fruit yield in melon. Plant Breed. 125: 482-487.

Zhang Y, Kang MS (1997). Diallel-SAS: A SAS program For Griffing's diallel analysis. Agron. J. 89(2): 176-182.

Zulfikri, Hayati E, Nasir M (2015). Phenotypic appearance, genetic parameters for yield character and yield component of melon (Cucumis melo). J. Floratek. 10(2): 1-11. 